THE WAR ON THE UYGHURS 
Princeton Studies in Muslim Politics

Dale F. Eickelman and Augustus Richard Norton, Series Editors

A list of titles in this series can be found at the back of the book 


\section{THE WAR ON THE UYGHURS}

\section{China's Internal Campaign against a Muslim Minority}

\section{SEAN R. ROBERTS}

Princeton University Press

Princeton and Oxford 
Copyright () 2020 by Princeton University Press

Published in the United States and Canada in 2020 by Princeton University Press 4I William Street, Princeton, New Jersey 08540

press.princeton.edu

First published in the United Kingdom in 2020 by Manchester University Press

Altrincham Street, Manchester MI 7JA

www.manchesteruniversitypress.co.uk

All Rights Reserved

Library of Congress Control Number 2020934178

ISBN 978-0-69I-202 I 8-I

ISBN (e-book) 978-o-69I-2022 I-I

Jacket image: Two ethnic Uyghur women pass Chinese paramilitary policemen standing guard outside the Grand Bazaar in the Uyghur district of the city of Urumqi in China's Xinjiang region, July I4, 2009. Peter Parks/AFP/Getty Images

Typeset by Servis Filmsetting Ltd, Stockport, Cheshire, UK

Printed on acid-free paper. $\infty$

Printed in the United States of America

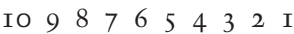


For my 'A-team' at home: Asel and Aideen Roberts 